\title{
Edukasi Berbasis Masyarakat untuk Deteksi Dini Diabetes Melitus Tipe 2
}

\author{
Citra Windani Mambang Sari, Ahmad Yamin, Sheizi Prista Sari \\ Fakultas Keperawatan, Universitas Padjadjaran \\ Email: citra.windani@unpad.ac.id
}

\begin{abstract}
Abstrak
Permasalahan kesehatan di Kota Bandung sangat kompleks. Salah satunya adalah Diabetes mellitus tipe 2 (DMT2) merupakan salah satu penyakit kronis yang angka kejadian dan komplikasi yang diakibatkannya terus meningkat dari waktu ke waktu. Kondisi tenaga kesehatan yang terbatas membutuhkan keterlibatan kader kesehatan sebagai pemberdayaan masyarakat agar masyarakat faham tentang Diabetes Melitus. Selain itu, masyarakat tidak pernah melakukan deteksi dini dan skrining gula darah. Kegiatan pengabdian ini dilakukan bertujuan untuk mengimplementasikan program edukasi berbasis masyarakat yang memfasilitasi masyarakat dalam menambah ilmu tentang deteksi dini dan perawatan diri Diabetes Melitus di Kebon Kangkung dan Kebon Jayanti Kota Bandung. Metodologi kegiatan pengabdian ini terdiri dari tiga tahapan, yaitu: 1) focused group; 2) tahapan implementasi; 3) evaluasi. Implementasi yang dilakukan skrining gula darah, pelatihan kader kesehatan, promosi kesehatan, konseling kelompok pada masyarakat yang beresiko. Edukasi dilakukan pada kader dengan memberikan pelatihan pada kader. Sebelum dan sesudah kegiatan pada kader diukur dengan menggunakan kuesioner Pengetahuan tentang DM dan selfefficacy. Setelah melakukan edukasi, pada minggu selanjutnya, kader melakukan deteksi dini DM pada masyarakat di Kelurahan. Analisis data menggunakan univariate dan bivariate. Hasil analisis adalah tidak ada perbedaan signifikan pada pengetahuan kader sebelum dan sesudah pelatihan (M (SD) sebelum = 7.84 (2.339), M(SD) sesudah 8.87 (3.22), $\mathrm{p}=0.066$ ) sedangkan ada perbedaan signifikan pada selfefficacy pada kader sebelum dan sesudah pelatihan (Median sebelum = 22, Median sesudah 25, $\mathrm{p}=0.000$ ). Sebagian besar masyarakat Kelurahan yang periksa gula darah mempunyai resiko sedikit meningkat terkena penyakit Diabetes Melitus. Simpulan dari kegiatan ini adalah adanya risiko sedikit meningkat terkena Diabetes pada masyarakat Kebon Jayanti dan Kebon Kangkung.
\end{abstract}

Kata kunci: Diabetes Melitus Tipe 2, Deteksi Dini, Perawatan Diri, Program Edukasi Berbasis Masyarakat.

\begin{abstract}
Health problems in Bandung are very complex. Diabetes one of the chronic diseases that the incidence and complications continue to increase over time. The limited condition of health workers requires the involvement of health cadres as community empowerment so that people understand about Diabetes Mellitus. In addition, the community has never carried out early detection and screening of blood sugar. The service was carried out with the aim of implementing a community-based education program that facilitates the community in adding knowledge about early detection and self-care of Diabetes Melitus in Kebon Kangkung and Kebon Jayanti Bandung. The methodology of this service activity consists of three stages, namely: 1) focused group; 2) implementation stages; 3) evaluation. Implementation was carried out by blood sugar screening, health cadres training, health promotion, group counseling in communities at risk. Education was carried out on cadres by providing training to cadres. Before and after activities on cadres were measured using a Knowledge questionnaire about DM and self-efficacy. After educating, in the following week, cadres conducted early detection of DM in the community in the village. Data analysis uses univariate and bivariate. The results of the analysis were that there were no significant differences in cadre knowledge before and after training $(M(S D)$ before $=7.84(2,339), M(S D)$ after 8.87 (3.22), $p=0.066)$ while there were significant differences in self-efficacy in cadres before and after training (Median before $=22$, Median after 25, $p=0.000$ ). Most of the urban community who check blood sugar have a slightly increased risk of developing diabetes mellitus. Conclusions from this activity are that there is a slightly increased risk of diabetes in the people of Kebon Jayanti and Kebon Kangkung.
\end{abstract}

Keywords: Community-based education, diabetes melitus, early detection, self-management. 


\section{Pendahuluan}

Berdasarkan International Diabetes Federation (IDF), Indonesia menempati urutan yang ke-7 untuk jumlah kasus penderita Diabetes Melitus (DM) dari usia 20-79 tahun terbanyak di dunia yaitu berjumlah 8,554 juta orang. Berdasarkan data Internasional Diabetic Federation (IDF) tahun 2011, Indonesia menduduki peringkat ke-9 terbanyak di dunia. Berdasarkan Riskesdas (2013) prevalensi diabetes di Jawa Barat mengalami peningkatan dari 1,1\% tahun 2007 menjadi 2,1\% dari jumlah penduduk pada tahun 2013. Sebagai ibu kota dari Jawa Barat, Bandung merupakan salah satu ibukota dimana tedapat $10 \%$ penduduknya mengidap penyakit diabetes (Tjandra, 2008). Berdasarkan Profil Kesehatan Kota Bandung (2011), penyakit diabetes juga menempati sepuluh terbesar pola penyakit di kota Bandung, pasien yang menjalani rawat jalan dengan diagnosa DM dengan tipe tidak spesifik adalah sebanyak 10.575 orang.

Penyakit diabetes juga mengakibatkan komplikasi. Komplikasi kronis paling utama adalah penyakit kardiovaskuler dan stroke, diabetic foot, retinopati, serta nefropati diabetika. Apabila dibandingkan dengan orang normal, maka penderita DM 5 kali Iebih besar untuk timbul gangren, 17 kali lebih besar untuk menderita kelainan ginjal dan 25 kali Iebih besar untuk terjadinya kebutaan. Berdasarkan IDF (2012) bahwa adanya komplikasi dan kematian akibat DM terbanyak berada pada usia produktif yaitu rentang usia 30 - 50 tahun. Dengan demikian, kematian pada penderita diabetes terjadi tidak secara langsung akibat peningkatan kadar gula darah, tetapi berhubungan dengan komplikasi yang terjadi.

Pengetahuan dan pemahaman tentang faktor risiko dan pencegahan Diabetes Melitus diperlukan. Penelitian tentang program edukasi penatalaksanaan Diabetes Melitus telah banyak dilakukan dengan banyak hasil pengukuran. Semua penelitian dilakukan pada pasien secara individual dengan setting di rumah sakit (Vatankhah et al, 2009 dan Kurniawan et al, 2011), di rumah (Lincoln et al, 2008, Sari, Haroen, Nursiswati 2016, dan Susanti, Haroen, Juniarti, 2011). Dari keempat penelitian tersebut hanya Susanti et al (2011) dan Sari et al (2016) yang melibatkan keluarga tetapi hanya dalam melakukan edukasi perawatan kaki, sedangkan Susanti et al (2011) pada penatalaksanaan DM. Hanya saja belum ada yang meneliti bagaimana perilaku perawatan diri pada pasien Diabetes Mellitus yang melibatkan komunitas. Menurut 
Friedman (2010), komunitas dapat dilibatkan sebagai sasaran edukasi perilaku perawatan diri pasien DM karena komunitas dapat menjadi pendorong anggota komunitas yang lain untuk melakukan suatu perilaku.

Edukasi penatalaksanaan DM dengan melibatkan kader juga sangat penting bagi anggota masyarakat yang lainnya, mengingat Diabetes Melitus merupakan penyakit herediter yang beresiko bagi anggota masyarakat yang lainnya. Selain itu, Diabetes Melitus merupakan penyakit kronis yang menurunkan kemampuan dari pasien, sehingga jika kader dilibatkan dalam program edukasi ini, masyarakat dapat membantu melakukan penatalaksanaan DM dan meningkatkan perilaku perawatan diri pada pasien saat kondisi pasien mulai memburuk. Berdasarkan penelitian McGowan (2011), program edukasi melibatkan komunitas meningkatkan perilaku perawatan diri pada pasien Diabetes Melitus. Ini sesuai dengan hasil penelitian ini, bahwa terdapat perbedaan bermakna $(p=0.000)$ pada kelompok intervensi setelah diberikan edukasi oleh kader dan kunjungan rumah oleh kader sebagai monitoring perilaku pasien. Hal ini sesuai dengan penelitian yang telah dilakukan di 4 Puskesmas bahwa keterlibatan kader kesehatan mempunyai pengaruh signifikan dalam perawatan diri pasien Diabetes Melitus (Sari et al, 2016).

Berdasarkan data pada rekam medis Puskesmas Babakan Sari pasien yang terdiagnosa Diabetes Melitus masih sedikit. Perawat Puskesmas melaporkan data tersebut merupakan data dari kunjungan rujukan pasien ke RS. Berdasarkan hasil wawancara yang dilakukan pada perwakilan masyarakat, kader PKK dan ibu kader, banyak warga yang belum pernah melakukan skrining gula darah. Hal ini dikarenakan Puskesmas tidak mempunyai alat untuk mengukur kadar gula darah. Selain itu, masih terdapat kekeliruan tentang faktor risiko, komplikasi serta perawatan diri pada pasien Diabetes Melitus.

Kondisi ini semakin dipersulit dengan masih terbatasnya jumlah sumber daya manusia, baik dari aspek kuantitas maupun kualitasnya, termasuk tenaga Perawat di Puskesmas. Untuk hal itu diperlukan keterlibatan kader dalam deteksi dini dan perawatan diri Diabetes Melitus dalam bentuk pelatihan kader kesehatan tentang deteksi dini dan perawatan diri Diabetes Melitus, skrining gula darah pada masyarakat dan pendidikan kesehatan tentang Diabetes Melitus. 
Diabetes tipe 2 umumnya terjadi pada saat pola gaya hidup dan perilaku sudah modern dan mapan. Pemberdayaan penyandang DM memerlukan partisipasi aktif pasien, keluarga dan masyarakat. Tim kesehatan mendampingi pasien dalam menuju perubahan perilaku sehat. Untuk mencapai keberhasilan perubahan perilaku, dibutuhkan edukasi yang komprehensif dan upaya peningkatan motivasi (Perkeni, 2011).

Edukasi merupakan salah satu proses berlangsung secara terus menerus, yang kemajuannya harus terus diamati. Tujuan pendidikan kesehatan pertama-tama untuk meningkatkan pengetahuan tentang DM. Pengetahuan tersebut akan menjadi titik tolak perubahan sikap dan gaya hidup mereka serta pada akhirnya adanya perubahan perilaku masyarakat dan pasien DM dan meningkatnya kepatuhan yang selanjutnya akan meningkatkan kualitas hidup pasien DM. Edukasi yang dilaksanakan pada kegiatan ini melibatkan komunitas yang ada di sekitar masyarakat.

Pemecahan masalah di atas adalah edukasi berbasis masyarakat. Edukasi berbasis masyarakat bukan hanya memberikan penyuluhan akan tetapi ada keterlibatan dari masyarakat. Keterlibatan masyarakat dalam deteksi dini dapat dilakukan melalui kader kesehatan dan masyarakat. Metode yang dilakukan dalam pemberian edukasi adalah pendidikan kesehatan menggunakan audio visual disertai kasus dan tanya jawab. Dalam aktivitasnya, kader kesehatan memerlukan kolaborasi dengan petugas kesehatan setempat, perwakilan dari masayarakat dan pimpinan masyarakat. Oleh karena itu, kader kesehatan membutuhkan dukungan, motivasi, instruksi dan pengawasan yang regular dari petugas kesehatan untuk memastikan kualitas hasil dipertahankan.

Pemilihan tempat penelitian adalah di wilayah kerja Puskesmas Babakan Sari yaitu di kelurahan Kebon Jayanti dan Kebon Kangkung, dikarenakan tempat ini cukup jauh dari Puskesmas Babakan Sari. Selain itu, wilayah kelurahan ini termasuk padat penduduk di Kota Bandung.

Ketua masyarakat berperan dalam memberikan izin untuk mengadakan perkumpulan dan memotivasi masyarakat, kader kesehatan, serta ibu PKK untuk terlibat dalam kegiatan ini. Ibu PKK terlibat dalam meningkatkan partisipasi masyarakat dan memberikan informasi kepada seluruh masyarak pada setiap kesempatan, dan kader kesehatan terlibat dari awal persiapan sampai dengan evaluasi kegiatan ini dan 
merupakan perpanjangan tangan dari pelaksana PKM ini. Kader kesehatan dan masyarakat merupakan peranan kunci dalam pengabdian masyarakat ini.

Pengabdian masyarakat ini bertujuan untuk mengimplementasikan program edukasi DM berbasis masyarakat sebagai upaya deteksi dini Diabetes Melitus di Kota Bandung.

\section{Metode}

Merode yang dilaksanakan terdiri dari 3 tahap yaitu tahap persiapan, tahap implementasi, dan tahap evaluasi. Pada fase persiapan, pengusul PPM mengumpulkan data dari puskesmas dan kemudian mapping pasien dengan diagnose Diabetes Melitus dilakukan pada kelurahan Kebon Jayanti dan Kebon Kangkung dengan menggunakan map titik. Pertemuan kelompok yang meliputi pengusul PPM, petugas kesehatan, kader PKK, dan pimpinan komunitas yang diwakili oleh Ketua RW 16. Kegiatan utama dari pertemuan ini adalah melakukan diskusi kelompok (focus discussion group) untuk melakukan penurunan faktor risiko Diabetes Melitus di wilayah ini dan kemudian diikuti oleh kegiatan analisa SWOT yang difasilitasi pada kegiatan PPM ini.

Fase pelaksanaan adalah fase edukasi berbasis masyarakat yang mana memiliki dua sasaran, yaitu pada masyarakat dan pasien Diabetes Melitus. Tahap pertama adalah kader kesehatan dilatih oleh pelaksana kegiatan PPM. Pemberian pelatiha dengan metode Ceramah tanya jawab dan role play. Tahap kedua adalah kader kesehatan yang telah dilatih mengimplementasikan program edukasi DM berbasis komunitas yang meliputi promosi kesehatan dan deteksi dini Diabetes Melitus. Kegiatan promosi kesehatan dan deteksi dini ini dilakukan oleh kader dan dibimbing oleh peneliti. Kader kesehatan memiliki peranan kunci dalam pelaksanaan program edukasi DM berbasis komunitas.

Fase evaluasi dilakukan dengan dua metode, yaitu evaluasi proses dan evaluasi hasil. Evaluasi proses terdiri dari pelaksanaan setiap aktivitas, kehadiran peserta, anstusias peserata, keaktifan, dan media dan strategi yang digunakan pada setiap 
aktivitas. Evaluasi hasil terdiri dari pengetahuan, sikap, perilaku kesehatan, selfefficacy, dan kepatuhan pelaksanaan program.

Instrumen self-efficacy pada kader dimodifikasi dari diabetes self-efficacy questionnaire yang dikembangkan oleh Standford Patients Education Research Center), intrumen pengetahuan dimodifikasi dari Michigan Diabetes Research and Training Center's Brief Diabetes Knowledge Test (Michigan University, 1998). Instrumen pengukuran risiko Diabetes Melitus menggunakan kuesioner Finnish Risk Diabetes dari Finnish Diabetes Association. Analisis data untuk pengetahuan dan self-efficacy pada kader menggunakan analisis bivariate. Hasil uji normalitas data pengetahuan pada kader adalah normal $(\mathrm{p}$ sebelum $=0.053, \mathrm{p}$ sesudah $=0.124)$, maka analisis menggunakan dependent t-test. Hasil uji normalitas data self-efficacy pada kader adalah tidak normal, sehingga menggunakan Wilcoxon. Analisis data pada hasil risiko dan gula darah pada masyarakat mengunakan analisis deskriptif dengan distribusi frekuensi.

\section{Hasil}

Tabel 1 Karakteristik Kader

\begin{tabular}{|c|c|c|c|}
\hline No & Variabel & $\mathbf{N}$ & Persentase (\%) \\
\hline \multirow[t]{4}{*}{1.} & Usia & & \\
\hline & $30-40$ tahun & 10 & 32.2 \\
\hline & 41- 50 tahun & 14 & 45.2 \\
\hline & 51- 60 tahun & 7 & 22.6 \\
\hline \multirow[t]{4}{*}{2.} & Status & & \\
\hline & Belum menikah & 1 & 3 \\
\hline & Menikah & 30 & 90.9 \\
\hline & Janda & 2 & 6.1 \\
\hline \multirow[t]{3}{*}{3.} & Suku & & \\
\hline & Sunda & 27 & 81.8 \\
\hline & Jawa & 6 & 18.2 \\
\hline \multirow[t]{3}{*}{4.} & Pekerjaan & & \\
\hline & Tidak bekerja & 31 & 93.9 \\
\hline & Wiraswasta & 2 & 6.1 \\
\hline \multirow[t]{5}{*}{5.} & Pendidikan & & \\
\hline & SD & 2 & 6.1 \\
\hline & SLTP & 13 & 39.4 \\
\hline & SLTA & 17 & 51.5 \\
\hline & Universitas & 1 & 3 \\
\hline
\end{tabular}




\begin{tabular}{lcc}
\hline Ya & 23 & 69.7 \\
Tidak & 10 & 30.3 \\
L. Lama menjadi kader & & \\
1-5 tahun & 14 & 43.8 \\
6-10 tahun & 10 & 31.2 \\
11-15 tahun & 6 & 18.8 \\
21-25 tahun & 1 & 3.1 \\
26-30 tahun & 1 & 3.1 \\
\hline
\end{tabular}

Dari tabel 1, usia kader yang mengikuti pelatihan sebagian besar lebih berusia 41-50 tahun (45.2\%). Hampir seluruh kader adalah tidak bekerja atau ibu rumah tangga (93.9\%). Tingkat pendidikan ibu kader, hampir sebagian besar adalah SLTA (51.5\%). Seluruh kader belum pernah mendapatkan edukasi terstruktur tentang Diabetes Melitus.

Sebelum diuji, hasil total skor pengetahuan sebelum dan sesudah masing masing kader diuji distribusi menggunakan Saphiro Wilk. Hasil untuk pengetahuan sebelum adalah. Dari hasil tersebut, maka distribusi data pengetahuan sebelum dan sesudah adalah normal. Analisis yang digunakan untuk uji inferensial menggunakan dependent t-test. Hasil uji normalitas pada self-efficacy adalah tidak normal maka uji inferensial menggunakan Wilcoxon.

Tabel 2 Hasil Uji Perbedaan Rata-Rata Pengetahuan Kader Sebelum dan Sesudah Pelatihan Kader tentang Perawatan DM ( $\mathrm{N}=31)$

\begin{tabular}{ccccc}
\hline Variabel & $\begin{array}{c}\text { Sebelum } \\
\text { M(SD) }\end{array}$ & $\begin{array}{c}\text { Sesudah } \\
\text { M (SD) }\end{array}$ & T & $\boldsymbol{P}$ \\
\hline Pengetahuan & $7.84(2.339)$ & $8.87(3.222)$ & -1.905 & 0.066 \\
\hline
\end{tabular}

Tabel 3 Hasil Uji Perbedaan Rata-Rata Self-Efficacy Kader Sebelum dan Sesudah Pelatihan Kader tentang Perawatan DM $(\mathrm{N}=31)$

\begin{tabular}{ccccc}
\hline Variabel & $\begin{array}{c}\text { Median } \\
\text { Sebelum }\end{array}$ & $\begin{array}{c}\text { Median } \\
\text { Sesudah }\end{array}$ & $\mathbf{Z}$ & $\mathbf{P}$ \\
\hline Self-efficacy & 22 & 25 & -3.321 & 0.000 \\
\hline
\end{tabular}

Pengetahuan kader yang dianalisis hanya 34 orang karena 3 orang meminta izin pulang lebih dulu. Berdasarkan Tabel 2, tidak ada perbedaan yang signifikan pengetahuan kader sebelum dan sesudah pelatihan kader tentang perawatan pasien DM. Hal ini dipengaruhi metode pelatihan dengan ceramah diskusi tanya jawab serta materi yang agak padat pada saat pelatihan. Ada perbedaan yang signifikan pada self-efficacy 
kader sebelum dan sesudah pelatihan. Hal ini dipengaruhi oleh motivasi yang diberikan pada saat pelatihan pada Ibu Kader kelurahan Kebon Kangkung dan Kebon Jayanti.

Tahap III diselenggarakan skrining gula darah sebanyak 59 orang. Skrining gula darah diselenggarakan pada saat kegiatan gebyar kesehatan di Kelurahan Kebon Kangkung dan Kebon Jayanti. Sebelum diselenggarakan skrining, peserta dikaji menggunakan kuesioner Finnish Risk Diabetes.

Tabel 4 Hasil FinRisk Diabetes $(\mathbf{N}=59)$

\begin{tabular}{lcc}
\hline \multicolumn{1}{c}{ Kriteria } & N & \% \\
\hline Resiko Rendah & 13 & 22 \\
Resiko sedikit meningkat & 26 & 44 \\
Resiko moderat & 8 & 13.6 \\
Resiko tinggi & 10 & 16.9 \\
Total & 2 & 3.4 \\
\hline
\end{tabular}

Tabel 5 Hasil Skrining Gula Darah $(\mathbf{N}=38)$

\begin{tabular}{ccccc}
\hline Variabel & Min & Max & Mean & SD \\
\hline Gula Darah & 53 & 389 & 137.58 & 77.068 \\
\hline
\end{tabular}

Berdasarkan Tabel 4, warga kelurahan Kebon Jayanti dan Kelurahan Kebon Kangkung memeriksakan gula darah, hampir sebagian besar memiliki resiko sedikit meningkat untuk terkena penyakit Diabetes Melitus. Resiko ini diidentifikasi dari usia, Body Mass Index (BMI), lingkar perut, aktivitas fisik, makan sayur dan buah-buahan, adanya penyakit sebelumnya dan genetik. Resiko sedikit meningkat untuk terkena DM bisa dicegah dengan olah raga, pola makan yang baik dan gaya hidup sehat. Berdasarkan Tabel 5, rata-rata hasil skrining gula darah 137.58 mg/dl. Hal ini menunjukkan bahwa rata-rata gula darah warga yang diperiksa menunjukkan hasil yang normal.

Kegiatan pengabdian ini merupakan aplikasi penerapan penelitian program edukasi berbasis Komunitas telah dilakukan peneliti sesuai dengan teori. Kegiatan ini melibatkan peran kader dalam proses edukasi yang diberikan kepada masyarakat. Pada pengetahuan kader, ada peningkatan pengetahuan yang dimiliki kader, walaupun secara analisis statistic tidak ada signifikansi. Peningkatan pengetahuan ini dikarenakan adanya edukasi yang diberikan oleh peneliti berupa audio visual, kasus serta tanya jawab. Menurut Sudiharto (2007), penyediaan bahan edukasi yang informatif dan menarik, sebagai pendukung yang sangat kuat dalam memberikan edukasi. 
Peningkatan self-efficacy pada kader setelah program edukasi berbasis masyarakat dikarenakan kader melihat kemampuan yang dimiliki untuk mendampingi warga masyarakat yag terkena DM. Kepercayaan diri (Self-efficacy) juga mempunyai kontribusi penting dalam meningkatkan perilaku perawatan diri pada responden dan keyakinan kader melaksanakan proses pendampingan pada pasien DM.

\section{Simpulan}

Hasil kegiatan pengabdian kepada masyarakat berjalan dengan lancar. Tidak ada perbedaan signifikan pada pengetahuan kader sebelum dan sesudah pelatihan $(\mathrm{p}=0.066)$ sedangkan ada perbedaan signifikan pada self-efficacy pada kader sebelum dan sesudah pelatihan $(\mathrm{p}=0.000)$. Sebagian besar warga desa yang periksa gula darah mempunyai resiko sedikit meningkat terkena penyakit Diabetes Melitus (26 orang dari 59 orang). Rata-rata hasil pemeriksaan gula darah adalah $137.58 \mathrm{mg} / \mathrm{dl}$.

Tindak lanjut yang harus dilaksanakan adalah skrining gula darah di RW yang lainnya difasilitasi dengan kader yang sudah dilatih sehingga kader dapat melaksanakan peran sebagai deteksi dini di masyarakat. Selanjutnya dapat dilakukan pendampingan oleh kader dengan menggunakan metode kelompok.

\section{Ucapan Terima kasih}

Peneliti mengucapkan terimakasih atas dukungan dari Direktur Riset Pengabdian Masyarakat Universitas Padjadjaran. Peneliti mengucapakan terimakasih atas kerjasama dari Kepala dan staf Kelurahan Kebon Jayanti dan Kebon Kangkung, kader dan masyarakat Kelurahan Kebon Jayanti dan Kebon Kangkung.

\section{Daftar Pustaka}

Dinas Kesehatan Provinsi Jawa Barat. (2012). Profil Kesehatan Provinsi Jawa Barat Tahun 2010. Dinas Kesehatan Provinsi Jawa Barat : Bandung.

International Diabetes Federation. (2013). IDF Diabetes Atlas sixth edition.

Kurniawan T, Sae-Sia W, Maneewat K, Petpichetchian W. (2011). The Effect of a self management Support Program on The Achievemnet Goal in Diabetic Foot Care Behaviours in Indonesian Diabetic Patients. Nurse Media Journal of Nursing, 1, 2 , 195-210. 
Lincoln NB, Radford KA, Game FL, Jeffcoate WJ. (2008). Education for Secondary Prevention of Foot Ulcers in people with Diabetes : a randomized Controlled Trial. Diabetologia, 51, 1954-1961.

McGowan, P. (2011). The Efficacy of Diabetes Patient Education and Self-Management Education in DM type 2. Canadian Journal of Diabetes35 (1) 46-53.

Perkeni. (2011). Penatalaksanaan Diabetes Melitus. PB. Perkeni. Jakarta.

Riskesdas. (2013). Laporan Nasional Kesehatan 2013. Diunduh dari google.com

Sari, CWM, Haroen H, Nursiswati. 2016. Pengaruh Program Edukasi Berbasis Keluarga Terhadap Perilaku Perawatan Kaki Pada Pasien Diabetes Melitius Di Wilayah Puskesmas Pasirkaliki Bandung. Jurnal Keperawatan Padjadjaran, Desember.

Susanti, S; Haroen H; Juniarti N. 2011. Pengaruh Diabetes Self Management Education (DSME) berbasis keluarga pada tingkat perawatan diri Pasien Diabetes Melitus di Kota Bandug. Tesis. Tidak dipublikasikan .

Vatankhah N, Khamseh ME, Noudeh YJ, Aghili R, Baradaran HR, Haeri NS. 2009. The Effectiveness Of Foot Care Education on People With Type 2 Diabetes in Tehran, Iran. Primary Care Diabetes 3, 73-77.

World Health Organization. (2010). Diabetes. Available at:http://www.who.int/topics/diabetes-melitus (diakses pada 03 Oktober 2012). 